\title{
Vertical interincisal trespass assessment in children with speech disorders
}

\begin{abstract}
Marcelo de Gouveia Sahad(a) Ana Carla Raphaelli Nahás ${ }^{(b)}$ Helio Scavone-Junior ${ }^{(b)}$ Luciana Badra Jabur ${ }^{(a)}$ Eduardo Guedes-Pinto(c)
\end{abstract}

(a) Research Fellows; (b) Associate Professors - Department of Orthodontics, University of São Paulo City, São Paulo, SP, Brazil.

(c) Professor and Chairman, Department of Orthodontics, University Cruzeiro do Sul, São Paulo, SP, Brazil.
Corresponding author: Marcelo de Gouveia Sahad R. Ministro Gabriel de Resende Passos, 92, apto. 71, Indianópolis

São Paulo - SP - Brazil CEP: 04521-020

E-mail:marcelosahad@terra.com.br

Received for publication on Oct 28, 2006 Accepted for publication on Nov 12, 2007

\begin{abstract}
Through a transversal epidemiological study, conducted with 333 Brazilian children, males (157) and females (176), aged 3 to 6 years old, enrolled in a public preschool, this study aimed to evaluate the prevalence of the different types of vertical interincisal trespass (VIT) and the relationship between these occlusal aspects and anterior lisping and/or anterior tongue thrust in the articulation of the lingua-alveolar phonemes /t/, /d/, /n/ and /l/. All children involved were submitted to a VIT examination and to a speech evaluation. Statistical significance was analyzed through the Qui-square test, at a significance level of 0.05 ( $95 \%$ confidence limit). The quantitative analysis of the data demonstrated the following prevalences: 1 - the different types of VIT: $48.3 \%$ for normal overbite (NO), $22.5 \%$ for deep overbite (DO), 9.3\% for edge to edge (ETE) and $19.8 \%$ for open bite $(\mathrm{OB}) ; 2$ - interdental lisping in relation to the different types of VIT: $42 \%$ for NO, $12.5 \%$ for DO, $12.5 \%$ for ETE, $32.9 \%$ for OB; and 3 - children with anterior tongue thrust in the articulation of lingua-alveolar phonemes in relation to the different types of VIT: $42.1 \%$ for NO, $14 \%$ for DO, $10.5 \%$ for ETE, $33.3 \%$ for OB. The results demonstrated that there was a significant relationship between open bite and anterior lisping and/or anterior tongue thrust in the articulation of the lingua-alveolar phonemes $/ \mathrm{t} /, / \mathrm{d} /, / \mathrm{n} /$ and $/ \mathrm{l} /$; and that there was a significant relationship between deep overbite and the absence of anterior lisping and anterior tongue thrust in the articulation of the lingua-alveolar phonemes.
\end{abstract}

Descriptors: Malocclusion; Open bite; Orthodontics; Speech disorders. 


\section{Introduction}

Dental malocclusions and anatomo-functional anomalies of the oral cavity are known to present remarkable interrelation. ${ }^{1}$ The modeling forces of the muscles over the dental arches, when well balanced and harmonious, favor adequate occlusion, and any alteration in the functional mechanism may lead to alterations in the bone development. When muscles perform their function, they model the bones and, in a certain way, direct their growth. Therefore, the existing relation between the oral cavity and the orofacial muscular system requires that all orthodontists know how to identify not only malocclusions but also functional and muscular orofacial alterations, so as to determine the best phase to refer the patient to a speech therapy clinic. ${ }^{2}$

Morphological alterations can thus trigger functional alterations, but not always will an alteration in form determine the presence of phonoarticulatory disorders. It is also believed that the organism presents a compensatory capacity in the face of its anatomical limitations. Nevertheless, these limitations may lead to speech disorders when they are not compensated adequately or when they require a greater degree of functional adaptation. Therefore, early intervention of both orthodontists and speech therapists, through myofunctional therapy, aids the prevention, during deciduous and mixed dentitions, of some occlusal anomalies, also contributing to the elimination of muscle forces contrary to the orthodontic treatment and favoring the stability of finalized treatments with a functionally ideal occlusion. ${ }^{2}$

Researches correlating speech and dental malocclusions often fail to be conclusive because these studies involve several different and highly complex factors, such as: populations, languages, methodologies, mental capacity, hearing capacity, environmental speech patterns, motivation ${ }^{3}$ and the combination of several occlusal anomalies and speech disorders in a single individual. ${ }^{4}$ However, speech disorders have been reported to be associated to different malocclusions, such as: Class II molars, ${ }^{5,6}$ Class III molars, ${ }^{7,8}$ deep overbite ${ }^{9,10}$ and open bite, ${ }^{7,11,12}$ the latter being the one that leads more frequently to speech disorders, as researchers have noticed a close relation between open bite and anterior lisping. ${ }^{7,8,12,13}$
As epidemiological studies demonstrate that malocclusions occur, on average, in $50 \%$ of the population, ${ }^{14,15}$ and since occlusal disharmony predisposes to phonoarticulatory alterations, consequently the latter will occur very frequently. Some authors also emphasize that children with pre-existing speech disorders may have their difficulties accentuated by the presence of dental malocclusion. ${ }^{4}$

Considering the aspects previously discussed, through a transversal epidemiological survey with 333 Brazilian children, aged 3 to 6 years old, enrolled in a public preschool in Tatuapé, a district in the eastern area of the city of São Paulo, this study aimed to determine the prevalences of the four types of vertical interincisal trespass (normal overbite, deep overbite, edge to edge and open bite) in the total sample, in the group with anterior lisping and in the group with anterior tongue thrust, in the articulation of the lingua-alveolar phonemes /t/, /d/, /n/ and $/ 1 /$, and to analyze statistically the interrelations between the occlusal characteristics studied and the phonoarticulatory alterations mentioned above.

\section{Material and Methods}

In this study, 333 clinical records belonging to the database of the Department of Orthodontics, University of São Paulo City (UNICID) were examined; they concerned Brazilian children, both male (157) and female (176), in the age range from 3 to 6 years, enrolled in a public preschool named Quintino Bocaiúva in Tatuapé, a district in the eastern area of the city of São Paulo.

In order to meet the purposes of this research, all children included in the study presented only deciduous teeth, without dental losses or extensive caries.

During the survey of the data, which are filed in the Discipline of Orthodontics of the University of São Paulo City, the professionals involved held a meeting aiming to inform the parents about the importance of the scientific research to the dental health of their children. It served to resolve doubts about the work project and how the clinical speech and dental examinations would be conducted. After the explanation, agreement of the adults in charge was requested in the form of a written authorization, so that the study could be continued. The ma- 
terials used by the dentists in the clinical dental examination were: gloves, aprons, caps and masks (all disposable) for the protective clothing of the professionals, and also disposable wooden tongue depressors and a clinical record form, in which relevant clinical data as well as the child's identification were recorded. The children were examined by two experienced speech therapists belonging to the faculty of the University of São Paulo City in order to assess clinically the presence of speech disorders, being of special interest to this research the presence or absence of anterior lisping and/or tongue thrust in the articulation of the lingua-alveolar phonemes /t/, /d/, $/ \mathrm{n} /$ and $/ 1 /$.

For assessment and classification of vertical interincisal trespass, the following criteria were employed:

- Normal overbite: the incisal edges of the maxillary incisors cover, at most, one third of the crown of the mandibular incisors;

- Deep overbite: the incisal edges of the maxillary incisors cover over one third of the crown of the mandibular incisors;

- Edge to edge: the vertical distance between the maxillary and mandibular incisal edges is zero; and

- Open bite: the incisal edges of the maxillary and mandibular incisors move away vertically in the apical direction, generating lack of occlusal contact between these teeth.

In the oral communication assessment, that is, the speech assessment, the examinations (Auxiliary Test - Personal Context, Word List - Monosyllables and Disyllables, Presentation of Pictures for Spontaneous Naming and Phonoarticulatory Assessment) were conducted individually with each child in the school environment in a room considered silent, so as to avoid external interferences.

Based on the clinical studies, a descriptive statistical analysis was done, including the calculation and tabulation of the prevalence of the four types of vertical interincisal trespass in percentage, and their relations with anterior lisping and/or anterior tongue thrust in the articulation of the phonemes $/ \mathrm{t} /, / \mathrm{d} /, / \mathrm{n} /$ and $/ \mathrm{l} /$. In the second step, statistical significance analysis was employed through the $\chi^{2}$ test (Qui-square), ${ }^{16}$ with a significance level of 0.05 ( $95 \%$ of confidence) to verify possible associations between the aforementioned speech problems and the various vertical occlusal relationships between the maxillary and the mandibular incisors in the group studied.

\section{Results}

The quantitative and statistical data concerning the distribution of the anterior vertical occlusal characteristics in relation to the phonoarticulatory problems studied in the total sample are presented in Tables 1, 2, 3 and 4.

\section{Discussion}

Until today little is known about the primary determining factors of mal-occlusions. In most of the cases the morphofunctional characteristics of dental occlusion are inherited towards normality, since genetic characters are usually dominant. However, the elements that participate in the development and maintenance of these characteristics of normality are numerous and sensitive, mainly in their interre-

Table 1 - Prevalence of the different types of vertical interincisal trespass in the sample studied.

\begin{tabular}{l|r|r}
\hline Types of vertical interincisal trespass & $\mathrm{n}$ & $\%$ \\
\hline Normal overbite & 161 & 48.3 \\
\hline Deep overbite & 75 & 22.5 \\
\hline Edge to edge & 31 & 9.3 \\
\hline Open bite & 66 & 19.8 \\
\hline Total & 333 & 100.0 \\
\hline
\end{tabular}

Table 2 - Prevalence of the types of vertical interincisal trespass in the sample in relation to the presence or absence of anterior lisping.

\begin{tabular}{l|c|c|c|c}
\hline \multirow{2}{*}{$\begin{array}{c}\text { Types of vertical } \\
\text { interincisal } \\
\text { trespass }\end{array}$} & \multicolumn{2}{|c|}{$\begin{array}{c}\text { Children with Anterior } \\
\text { lisping }\end{array}$} & \multicolumn{2}{c}{$\begin{array}{c}\text { Children without } \\
\text { Anterior lisping }\end{array}$} \\
\cline { 2 - 5 } & $\mathrm{n}$ & $\%$ & $\mathrm{n}$ & $\%$ \\
\hline Normal overbite & 37 & 42.0 & 124 & 50.6 \\
\hline Deep overbite & 11 & 12.5 & 64 & 26.1 \\
\hline Edge to edge & 11 & 12.5 & 20 & 8.2 \\
\hline Open bite & 29 & 32.9 & 37 & 15.1 \\
\hline Total & 88 & 100.0 & 245 & 100.0 \\
\hline
\end{tabular}


Table 3 - Prevalence of the types of vertical interincisal trespass in the sample in relation to the presence or absence of anterior tongue thrust in the articulation of the lingua-alveolar phonemes /t/, /d/, /n/ and /l/.

\begin{tabular}{l|c|c|c|c}
\hline \multirow{2}{*}{$\begin{array}{c}\text { Types of vertical } \\
\text { interincisal } \\
\text { trespass }\end{array}$} & \multicolumn{2}{|c|}{$\begin{array}{c}\text { Children with Anterior } \\
\text { tongue thrust }\end{array}$} & \multicolumn{2}{|c}{$\begin{array}{c}\text { Children without } \\
\text { Anterior tongue thrust }\end{array}$} \\
\cline { 2 - 5 } & $\mathrm{n}$ & $\%$ & $\mathrm{n}$ & $\%$ \\
\hline Normal overbite & 48 & 42.1 & 113 & 51.5 \\
\hline Deep overbite & 16 & 14.0 & 59 & 26.9 \\
\hline Edge to edge & 12 & 10.5 & 19 & 8.6 \\
\hline Open bite & 38 & 33.3 & 28 & 12.7 \\
\hline Total & 114 & 100.0 & 219 & 100.0 \\
\hline
\end{tabular}

lations. As a result, any modification in the functional mechanism (breathing, swallowing, articulation and chewing) may alter the form, as well as the form may alter the function, consequently determining morphofunctional deviations and deformities. ${ }^{10,11,17,18}$ It is worth remembering that although the bone tissue is one of the hardest of the human body, it is also one of the most plastic and one of the most responsive to the forces generated during function. ${ }^{7}$

Muscle forces also influence dental positioning according to their duration and intensity. The forces resulting from articulation and swallowing, which are intermittent and of greater intensity in relation to resting forces, considered of lower intensity and continuous, do not present great influence on the teeth. ${ }^{9}$ Thus, as concerns speech, many researchers have not obtained conclusive results in the attempt to correlate phonoarticulatory problems with malocclusions and deviations in the dimensions of the oral structures. However, such relationships have not been completely discarded, and there is an agreement among authors that further studies should be carried out, aiming at a greater clarification of this relation. . $^{1-2,9,19,20,21}$

The tongue is considered the most important organ in the articulation of speech due to its ability to present fast changes of movement and shape. When any type of abnormality prevents its normal articulation with the related structures (lips, teeth, alveolar bones, hard palate and soft palate), this may result in a speech disorder. ${ }^{13,16}$
Table 4 - Relation of the different types of vertical interincisal trespass with anterior lisping and anterior tongue thrust (Anterior T. T.) in the articulation of the lingua-alveolar phonemes /t/, /d/, /n/ and /l/. The table shows the Qui-square value, $\mathrm{p}$-value, and the statistical significance of the results.

\begin{tabular}{c|c|c|c}
\hline $\begin{array}{c}\text { Types of vertical } \\
\text { interincisal trespass }\end{array}$ & & Anterior lisping & Anterior T. T. \\
\hline \multirow{4}{*}{ Normal overbite } & Qui & 1.575 & 2.339 \\
\cline { 2 - 4 } & $p$ & 0.209 & 0.126 \\
\cline { 2 - 4 } & Sig. & NS & NS \\
\hline \multirow{4}{*}{ Deep overbite } & Qui & 6.127 & 6.435 \\
\cline { 2 - 4 } & $p$ & 0.013 & 0.011 \\
\cline { 2 - 4 } & Sig. & $0.05^{*}$ & $0.05^{*}$ \\
\hline \multirow{3}{*}{ Edge to edge } & Qui & 0.974 & 0.124 \\
\cline { 2 - 4 } & $p$ & 0.324 & 0.724 \\
\cline { 2 - 4 } & Sig. & NS & NS \\
\hline \multirow{4}{*}{ Open bite } & Qui & 11.886 & 18.647 \\
\cline { 2 - 4 } & $p$ & 0.001 & $1.573 \mathrm{E}-05$ \\
\cline { 2 - 4 } & Sig. & $0.001^{*}$ & $0.001^{*}$ \\
\hline
\end{tabular}

"Statistically significant difference $(p<0.05)$.

Some researchers have concluded that the human organism has a natural tendency to compensate the posture of the functional muscle group when there are structural problems (malocclusions), in the attempt to obtain the correct articulation of phonemes. ${ }^{5,8,11,13,20}$ It is important to stress that there should be a detailed assessment of the cases in which the organism cannot compensate functionally the morphological deficiencies, in order to define a correct diagnosis, treatment plan and prognosis, helping in the orthodontic treatments and avoiding possible recidivism. ${ }^{8,11}$

Several authors have established a relationship between phonoarticulatory problems and the different types of dental malocclusions, among which open bite is the malocclusion more often associated to the presence of anterior lisping and anterior tongue thrust in the articulation of the lingua-alveolar phonemes, ${ }^{1,4,9,10,12-16,19,20,21}$ which is in agreement with the results found in this research.

Bearing in mind the aspects previously discussed, the present study intended to assess the prevalence and the interrelations of the different types of vertical interincisal trespass, of anterior lisping and of anterior tongue thrust in the articulation of the lin- 
gua-alveolar phonemes /t/, /d/, /n/ and /l/ in the deciduous dentition.

\section{Conclusions}

According to the results obtained, the following conclusions were drawn:

1. there was a significant relationship between open bite and anterior lisping and/or anterior tongue thrust in the articulation of the lingua-alveolar phonemes /t/, /d/, /n/ and /l/;

2. there was a significant relationship between deep overbite and the absence of anterior lisping and

\section{References}

1. Bernstein M. The relation of speech defects and malocclusion. Am J Orthod. 1954;40:149-50.

2. Blyth $P$. The relationship between speech, tongue behaviour, and occlusal abnormalities. Dent Pract Dent Rec. 1959;10:11-20.

3. Rathbone JS. Appraisal of speech defects in dental anomalies. Angle Orthod. 1955;25(1):42-8.

4. Laine T. Malocclusion traits and articulatory components of speech. Eur J Orthod. 1992;14(4):302-9.

5. Farret MMB, Jurach EM, Brandão L, Moraes DCF, Brandão SRS, Santos SL. Relationship between malocclusion and fonoarticulatory disorders. Int J Orofacial Myology. 1998;24:20-6.

6. Galvão CAAN, Pereira CB, Bello DRM. Prevalência de má oclusões na América Latina e considerações antropológicas. Ortodontia. 1994;27(1):51-9.

7. Graber TM. Ortodoncia: teoria y practica. Garcia JL, trad. $3^{a}$ ed. México: Interamericana; 1974.

8. Guay AH, Maxwell DL, Beecher R. A radiographic study of tongue posture at rest and during the phonation of /s/ in class III malocclusion. Angle Orthod. 1978;48(1):10-22.

9. Ingervall B, Sarnäs KV. Comparison of dentition in lispers and non-lispers. Odontol Revy. 1962;13:344-54.

10. Jabur LB. Inter-relação entre forma e função na cavidade oral. In: Marchesan IQ, Bolffi C, Gomes ICD, Zorzi JL. Tópicos em Fonoaudiologia. São Paulo: Lovise; 1994. p. 223-5.

11. Jabur LB. Avaliação Fonoaudiológica. In: Ferreira FV. Ortodontia - diagnóstico e planejamento clínico. $5^{\text {a }}$ ed. São Paulo: Artes Médicas; 2002. p. 281-319. anterior tongue thrust in the articulation of the lingua-alveolar phonemes /t/, /d/, /n/ and /l/; and

3. there was no significant relationship between normal overbite or edge to edge occlusion and the phonoarticulatory occurrences studied.

Although the results indicate a positive relationship between the phonoarticulatory problems with open bite, our analysis of the occlusal characteristics should be complemented by study of all the associated orofacial structures and the facial pattern in order to assess the relationship between speech disorders and malocclusions.

12. Junqueira PS. Ocorrência de ceceio anterior interdental em crianças de 3 a 8 anos e sua relação com idade e oclusão dental [Dissertação de Mestrado]. São Paulo: Pontifícia Universidade Católica de São Paulo; 1994.

13. Keith K, Schaaf NG. The effects of dental abnormalities on speech production. Quintessence Int. 1982;13(12):1353-62.

14. Klechak TL, Bradley DP, Warren DW. Anterior open bite and oral port constriction. Angle Orthod. 1976;46(3):232-42.

15. Laine T. Associations between articulatory disorders in speech and oclusal anomalies. Eur J Orthod. 1987;9(2):144-50.

16. Laine T, Jaroma M, Linnasalo AL. Relationships between interincisal occlusion and articulatory components of speech. Folia Phoniatr. 1987;39(2):78-86.

17. Lino AP. Introdução ao problema da deglutição atípica. In: Interlandi S. Ortodontia. Bases para a iniciação. São Paulo: EDUSP; 1997. p. 231-50.

18. Marchesan IQ. The speech pathology treatment with alterations of a stomatognathic system. Int J Orofacial Myology. 2000;26(5):5-12.

19. Cayley AS, Tindall AP, Sampson WJ, Butcher AR. Electropalatographic and cephalometric assessment of tongue function in open bite and non-open bite subjects. Eur J Orthod. 2000;22(5):463-74.

20. Coleman RO, Gullikson JS. Speech problems in children. J Dent Child. 1971;28(6):381-4.

21. Lubit EC. The relationship of malocclusion and faulty speech articulation. J Oral Med. 1967;22(2):47-55. 